https://doi.org/10.28925/2226-3012.2021.105

УДК 378.4.01:17.022.1](477+438)

\title{
Олена Проченко
}

ORCID iD 0000-0001-5046-854X

кандидат педагогічних наук, доцент,

завідувач науково-дослідної лабораторії освітології,

Київський університет імені Бориса Грінченка,

вул. Тимошенка, 13-б, 04212 Київ, Україна,

o.protsenko@kubg.edu.ua

\section{Оксана Бульвінська}

ORCID iD 0000-0002-6764-4340

кандидат педагогічних наук, старший науковий співробітник,

старший науковий співробітник науково-дослідної лабораторії освітології,

Київський університет імені Бориса Грінченка,

вул. Тимошенка, 13-6, 04212 Київ, Україна,

o.bulvinska@kubg.edu.ua

\section{Ольга Мельниченко}

ORCID iD 0000-0002-5297-9551

кандидат історичних наук, доцент,

доцент кафедри теорії та історії педагогіки

Педагогічного інституту,

Київський університет імені Бориса Грінченка,

бульвар I. Шамо 18/2,

melnychenko@kubg.edu.ua

\section{Ярослав Хархула}

ORCID iD 0000-0002-8470-7374

доктор гуманітарних наук у галузі соціології (PhD),

заступник директора Інституту педагогічних наук із дидактики,

Академія Ігнатіанум у Кракові,

вул. Коперніка 26, 31-501 Краків, Республіка Польща,

jaroslaw.charchula@ignatianum.edu.pl

\section{УНІВЕРСИТЕТСЬКІ ЦІННОСТІ В ЗАКЛАДАХ ВИЩОЇ ОСВІТИ УКРАЇНИ ТА РЕСПУБЛІКИ ПОЛЬЩА: ПОГЛЯД СТУДЕНТІВ}

\footnotetext{
У статті на основі власного експериментального дослідження проведений порівняльний аналіз ставлення студентів українських і польських закладів вищої освіти до університетських цінностей. Наголошено, що морально-етичні цінності академічної культури, сформульовані в "Декларації етичних цінностей і принципів вищої освіти в Європі», реалізуються в усіх аспектах діяльності європейських університетів, зокрема польських. Україна, стратегічною метою якої є входження до Європейського Союзу, ресормує систему освіти відповідно до цінностей Європейського простору вищої освіти. Акцентовано, що система спільних цінностей, відносин, норм, звичок, традицій, форм поведінки і ритуалів, не тільки задекларованих, а й підтриманих усіма членами університетської спільноти, є важливим елементом унікальної корпоративної культури закладу вищої освіти, що визначає його організачійний успіх, сприяє підвищенню якості освіти. Дослідження, проведене на основі опитування студентів Педагогічного інституту Київського університету імені Бориса Грінченка і педагогічного факультету Єзуїтського університету Ігнатіанум, виявило, що польські студенти виявляють більшу прихильність до європейських цінностей, які задекларовані і послідовно впроваджуються в Європейському просторі вищої освіти; українські студенти більшою
} 
мірою орієнтовані на індивідуальні цінності. Ці результати підтверджують відмінності у політично-аксіологічному статусі двох країн.

Ключові слова: вища освіта; Європейський простір вищої освіти; корпоративна університетська культура; студенти; університетські цінності.

(с) Проценко Олена, Бульвінська Оксана, Мельниченко Ольга, Хархула Ярослав, 2021

Вступ. Формування і розвиток системи цінностей - одне з центральних питань у всіх гуманітарних науках, перш за все у філософії, соціології, педагогіці, психології. Проблема трансформації цінностей набуває особливої гостроти, оскільки процеси глобалізації, становлення інформаційного суспільства прискорюють темп життя, пропонують поліфонію цінностей та ідеологічних настанов, зростає потік інформації, швидко змінюється соціальний статус людини, а отже, особистість має вибирати світоглядні пріоритети в цих складних умовах швидкозмінюваних життєвих реалій і розмаїття ціннісних орієнтирів.

Освіта, зокрема вища - це фундаментальна основа і одне 3 джерел формування системи пріоритетних культурно-світоглядних цінностей особистості. Проте завдання вищої освіти значно ширше, ніж просто готувати нові покоління до діяльної участі у моральній нормотворчості в усіх сферах суспільного життя та усіх різновидах соціальних практик. Університети як важливий елемент системи формування соціального капіталу країни стають перехрестям соціального співробітництва, формують навколо себе атмосферу соціальної довіри, служать формуванню справедливого суспільства. Отже, науковці розглядають університет як важливий елемент визначення моральної позиції для сучасного суспільства, а необхідним i значущим кроком на шляху вдосконалення системи освіти - розроблення іiі ціннісного каркаса (Boychenko, 2016).

Морально-етичні цінності академічної культури, які складають основу для розвитку знань, забезпечення якості освіти і підготовки студентів як відповідальних громадян і кваліфікованих фахівців, були сформульовані в 2004 р. в Бухарестській «Декларації етичних цінностей і принципів вищої освіти в Європі». Ключовими цінностями сумлінного академічного співтовариства в Декларації визнані чесність, довіра, прямота, повага, відповідальність і підзвітність (The Bucharest Declaration, 2004). Ці цінності Європейського простору вищої освіти не тільки покладені в основу задекларо- ваних місії, кодексу чи статуту закладів вищої освіти, а й реалізуються в усіх аспектах діяльності університетів: освітній, науковій, внутрішньому управлінні, відносинах із зовнішніми стейкхолдерами. Це передбачає певний рівень свідомості всіх учасників освітнього процесу і породжує відповідальність як особистісну, так і інституційну.

Система спільних цінностей, відносин, норм, звичок, традицій, форм поведінки і ритуалів $\epsilon$ важливим елементом університетської корпоративної культури. Не просто прописані в стратегіях, уставах та інших засадничих документах, а підтримані всіма членами університетської спільноти, вони впливають на особистісні цінності, потреби, моральні норми кожного учасника освітнього процесу, а дотримання норм моралі і цінностей в закладі вищої освіти є тим позитивним фактором, що сприяє формуванню культури якості в університеті. Ефективність функціонування корпоративної культури університету, як відзначають дослідники, може визначити його організаційний успіх (Holten and Brenner, 2015). Коли студенти сприймають свій університет як відмінний від інших у цінностях та освітній практиці і поділяють його цінності, то це підвищує привабливість закладу вищої освіти для усіх стейкхолдерів і його конкурентоспроможність, адже, по-перше, університет залучає більше абітурієнтів, а по-друге, підтримує зв'язок з випускниками-роботодавцями (Jaakson, 2008; Amir et al., 2016).

Особливу увагу в дослідженнях науковці приділяють не тільки сприйняттю студентами університетських цінностей, а й участі їх у формуванні системи цінностей закладу вищої освіти (Dollinger and Lodge, 2020; Dollinger and Mercer-Mapstone, 2019), систематизуючи різні студентські ролі в цьому процесі: студенти як споживачі; студенти як продюсери; студенти як співавтори; студенти як партнери; студенти як агенти змін (Kay, Owen, \& Dunne, 2012; Dollinger and Mercer-Mapstone, 2019).

Окрему групу складають наукові дослідження, присвячені університетським цінностям, яких очікують студенти, вступаючи 
до певного закладу вищої освіти. Науковці підкреслюють (Cavallone, Ciasullo, Manna, \& Palumbo, 2020; Dlačić, Arslanagić, KadićMaglajlić, Marković, and Raspor, 2013), що довіра до університетських цінностей стимулює не тільки бажання студентів встановити довгострокові стосунки з закладами вищої освіти, а й їхню готовність до співтворення цінностей у партнерстві з академічним персоналом.

У науковій літературі досить широко розглядається поєднання досвіду студентів та академічного персоналу в співтворчості університетських цінностей, що сприяє підвищенню якості та ефективності освітніх послуг (Hilton, Hughes, and Chalcraft, 2012; Dollinger, Lodge, and Coates, 2018; Hughes, and Brooks, 2019; Cavallone, Ciasullo, Manna, \& Palumbo, 2020). ЯК відзначає K. Dziewanowska (2017), хоча співтворчість цінностей відбувається в розширеній мережі різних зацікавлених сторін, все ж основну роль відіграють відносини між студентом і викладачем як основними стейкхолдерами вищої освіти.

У контексті вивчення міжкультурних відмінностей певний інтерес становлять дослідження ставлення до університетських цінностей студентів різних країн: Естонії (Jaakson, 2008); Чexiï (Fajćíková and Urbancová, 2019); Iспаніï (Vilà, Aneas, Rubio, J., Freixa, 2019); Бразилії (Sampaio, Perin, Simões, and Kleinowski, 2012), а також порівняння результатів з різних країн (Mamica, Mazur, 2020).

Мета статті. Наша наукова розвідка мала на меті провести порівняльний аналіз ставлення студентів українських і польських закладів вищої освіти до університетських цінностей, базуючись на нашому власному експериментальному дослідженні. Щоб виявити ставлення студентів до університетських цінностей, а також для того, щоб простежити будь-які відмінності чи подібності у поглядах українських та польських студентів, ми провели емпіричне дослідження за допомогою опитування, яке охопило цілу низку якісних параметрів щодо таких дослідницьких питань:

1. Як сприймають українські та польські студенти університетські цінності?

2. Чи є суттєва різниця у ранжуванні цінностей студентами українських та польських університетів?

Методи дослідження. Для досягнення мети нашої статті було проведене опитування студентів двох університетів: Київського університету імені Бориса Грінченка (Україна) і Єзуїтського університету Ігнатіанум у Кракові (Республіка Польща). Вважаємо важливим порівняння досвіду університетів цих двох країн, що близькі за своєю історією та культурою. Проте існують важливі розбіжності: Польща пройшла шлях від постсоціалістичної держави до члена Європейського Союзу; Україна тільки реформує свою суспільно-політичну систему (і систему освіти, як складову соціальної системи, зокрема) відповідно до європейських стандартів. Тому досвід Польщі як країни члена Європейського Союзу дуже важливий для врахування в українській вищій освіті, зокрема - ставлення здобувачів вищої освіти до морально-етичних цінностей Європейського простору вищої освіти.

Київський університет імені Бориса Грінченка - заклад вищої освіти Київської комунальної власності. Його місія - служити людині, громаді, суспільству - грунтується на таких цінностях: людина, громада, довіра, духовність, лідерство-служіння, відповідальність, професіоналізм, громадянська ідентичність, свобода, різноманіття.

Єзуїтський університет Ігнатіанум у Кракові - це приватний католицький заклад вищої освіти, проте він офіційно визнаний польською державою. Місія університету в освітньому вимірі - формувати людину, яка $€$ зрілою в інтелектуальному, емоційному та духовному плані, відкритою для викликів сучасності, яка відповідально та творчо реалізує свою професійну та соціальну відданість з повагою до власної та іншої людської гідності та здатна слідувати принципу «ad maiorem Dei gloriam» («для більшої слави Божої») в житті.

Отже, незважаючи на відмінності в організаційних і світоглядних засадах, обидва університети своєю ціннісною основою проголошують підготовку високопрофесійного фахівця, відповідального, творчого, орієнтованого на соціальне служіння.

Для опитування ми вибрали майбутніх педагогів: студентів Педагогічного інституту Київського університету імені Бориса Грінченка і педагогічного факультету Єзуїтського університету Ігнатіанум, оскільки саме від педагогічних працівників багато в чому залежить якість вищої освіти і перспективи розвитку країни в цілому. Саме вчителі $\epsilon$ агентами змін, які здатні відповісти на освітні виклики сучасності і змінити систему освіти у відповідності до них.

Опитування було проведено онлайн за Google-формою. Усього в опитуванні взяло 
участь 206 українських і 151 польських студентів. Отже, загальна вибірка складала 357 здобувачів вищої освіти. Опитування було анонімним. Серед респондентів у Польщі 73\% студентів першого (бакалаврського) і $27 \%$ - другого (магістерського) рівня вищої освіти. Процентний розподіл українських студентів майже не відрізняється: 71\% студентів першого (бакалаврського), 27\% - другого (магістерського), 2\% третього (освітньо-наукового) рівня вищої освіти. Інформацію про кількісні та якісні показники учасників опитування наведено в Табл. 1.

Таблиия 1.

Освітній рівень респондентів анкетування «Ставлення студентів до університетських цінностей»

\begin{tabular}{|c|c|c|c|c|c|c|}
\hline & \multicolumn{2}{|c|}{ Українські студенти } & \multicolumn{2}{|c|}{ Польські студенти } & \multicolumn{2}{|c|}{ Усі респонденти } \\
\hline & Кількість & $\%$ & Кількість & $\%$ & Кількість & $\%$ \\
\hline $\begin{array}{l}\text { Освітній рівень: } \\
\text { перший (бакалаврський) } \\
\text { другий (магістерський) } \\
\text { третій (освітньо-науковий) }\end{array}$ & $\begin{array}{l}146 \\
55 \\
5\end{array}$ & $\begin{array}{l}71 \\
27 \\
2\end{array}$ & $\begin{array}{l}110 \\
41\end{array}$ & $\begin{array}{l}73 \\
27\end{array}$ & $\begin{array}{l}256 \\
96 \\
5\end{array}$ & $\begin{array}{l}72 \\
27 \\
1\end{array}$ \\
\hline
\end{tabular}

Джерело: складено самостійно

Результати дослідження i дискусія. На питання «Чи вважаєте Ви, що заклад вищої освіти повинен формувати моральні норми і цінності в студентів?», більшість українських і польських студентів дали позитивну відповідь (Рис. 1). Проте є відмінності у кількості негативних відповідей: чверть українських студентів вважають, що завдання 3 ВО готувати до майбутньої професії, а моральні норми мають бути сформовані сім'єю і середньою освітою; $11 \%$ не визначились із відповіддю. Польські студенти налаштовані більш оптимістично: позитивних відповідей майже на 15\% більше, негативних відповідей мінімальна кількість, але $22 \%$ опитаних не визначилися із відповіддю. Вважаємо, що така різниця пов'язана, по-перше, 3 релігійною спрямованістю польського університету, яка передбачає високі моральні якості і ціннісні орієнтації студентів. Другою причиною вважаємо невизначений статус ціннісно-ідеологічних настанов в Україні, а також ціннісні протиріччя в країні, які стали однією з причин дестабілізації суспільних відносин.

\section{Чи вважаєте Ви, що заклад вищої освіти повинен формувати моральні норми і цінності в студентів?}

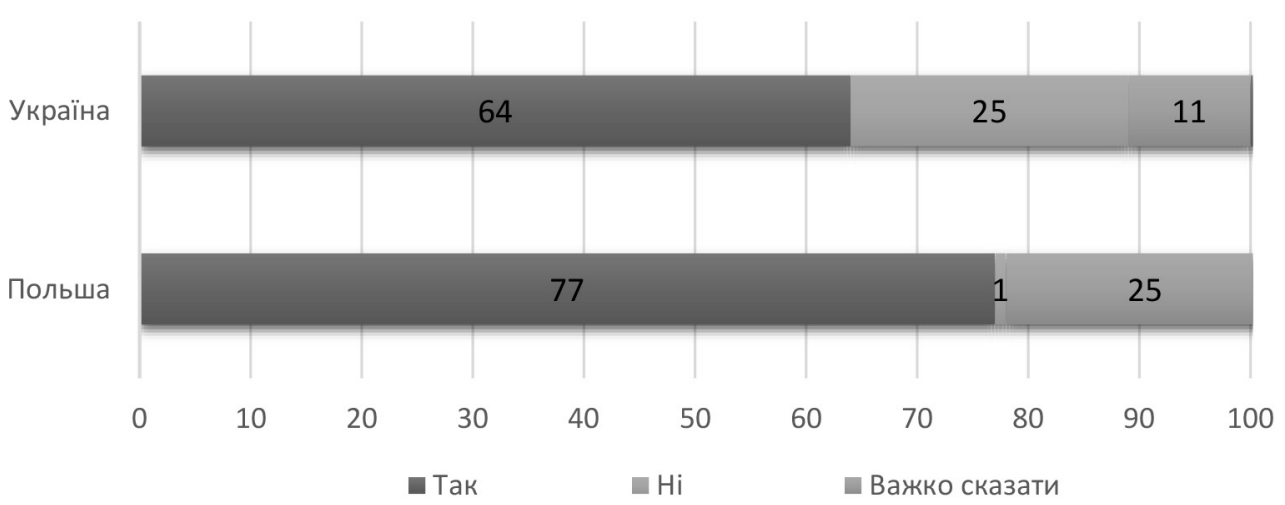

Puc. 1. Розподіл відповідей на питання «Чи вважаєте Ви, що заклад вищої освіти повинен формувати моральні норми і цінності в студентів?

Джерело: складено самостійно

Переважно позитивною була відповідь студентів обох країн на питання «Чи впливає, на Вашу думку, дотримання норм моралі і цінностей на формування професійних якостей особистості?» (Рис. 2), хоча 25\% польських студентів вважають це твердження лише частково правильним (для порівняння: українських відповідей було удвічі менше). 


\section{Чи впливає, на Вашу думку, дотримання норм моралі і цінностей на формування професійних якостей особистості?}

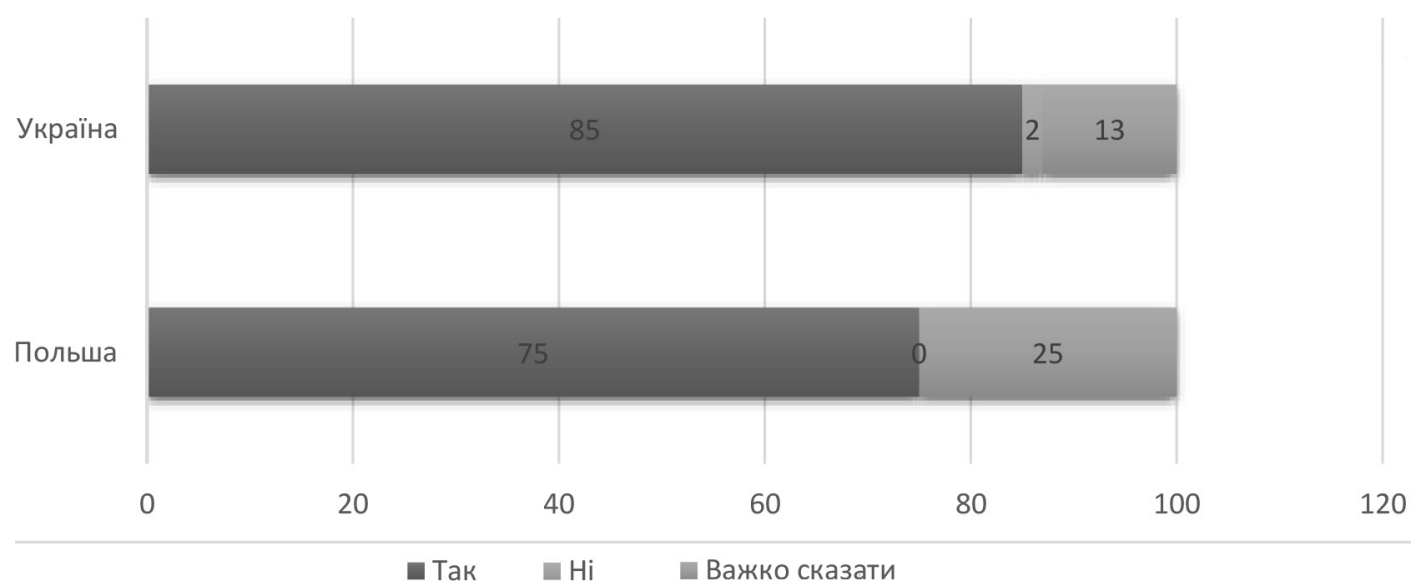

Puc. 2. Розподіл відповідей на питання «Чи впливає, на Вашу думку, дотримання норм моралі і цінностей на формування професійних якостей особистості?

Джерело: складено самостійно

Щоб проаналізувати важливість цінностей в різних університетах, ми склали їхній перелік і запропонували респондентам розмістити цінності за ієрархією їхнього уподобання (від 1 до 10, де 1 - це найвищий рівень), щоб у підсумку отримати їх рейтингову шкалу в розумінні українських і польських студентів.

Формулювання питань анкети спиралися на формулювання ключових цінностей 3 «Декларації етичних цінностей і принципів вищої освіти в Європі», а також на місії і основні положення Кодексів корпоративної культури обох університетів. У переліку ми визначили цінності, найбільш значущі для держави, для соціуму (у межах нашого дослідження ми обрали корпоративну академічну спільноту університету) і для особистості (це розділення умовне, оскільки чіткої межі між трьома шарами цінностей немає: вони взаємообумовлені і перебувають у процесі взаємодії і взаємопереходу):

1) Державні иінності:

• громадянська ідентичність;
2) Суспільні иінності:

- загальнолюдські моральні цінності;

- толерантність;

- корпоративні цінності університету;

- лідерство-служіння;

- академічна доброчесність;

3) Особистісні иінності:

- вільний розвиток особистості;

- різноманіття розвитку особистості; - свобода професійної діяльності;

- відповідальність та професіоналізм.

Результати опитування було оброблено за допомогою програми IBM SPSS Statistics. U-тест Манна-Уїтні (якщо вибірка більше 20 респондентів, то вираховують Z-значення) виявив статистично значущі відмінності у всіх групах відповідей українських і польських студентів, окрім цінності «відповідальність та професіоналізм», де показник $p$ засвідчує відсутність статистичної різниці. Результати статистичної обробки результатів представлені в Табл. 2.

Таблиия 2

Порівняння університетських цінностей українських і польських студентів за U-тестом Манна-Уїнні

\begin{tabular}{|c|c|c|c|c|c|}
\hline $\begin{array}{l}\text { № } \\
\text { 3/II }\end{array}$ & Цінність & Країна & Медіана & $\begin{array}{c}\text { Результати тесту, } \\
\mathrm{Z} \\
\end{array}$ & $\begin{array}{l}\text { Статистична } \\
\text { значущість, p }\end{array}$ \\
\hline \multirow{2}{*}{1} & \multirow{2}{*}{ вільний розвиток особистості } & Польща & 8,00 & \multirow{2}{*}{$-7,268$} & \multirow{2}{*}{$<0,001$} \\
\hline & & Україна & 4,00 & & \\
\hline \multirow{2}{*}{2} & \multirow{2}{*}{$\begin{array}{c}\text { загальнолюдські моральні } \\
\text { цінності }\end{array}$} & Польща & 9,00 & \multirow{2}{*}{$-10,151$} & \multirow{2}{*}{$<0,001$} \\
\hline & & Україна & 4,00 & & \\
\hline
\end{tabular}


Продовження табл. 2

\begin{tabular}{|c|c|c|c|c|c|}
\hline $\begin{array}{l}\text { № } \\
3 / \text { II }\end{array}$ & Цінність & Країна & Медіана & $\begin{array}{c}\text { Результати тесту, } \\
\mathrm{Z} \\
\end{array}$ & $\begin{array}{r}\text { Статистична } \\
\text { значущість, p }\end{array}$ \\
\hline \multirow{2}{*}{3} & \multirow{2}{*}{$\begin{array}{c}\text { корпоративні цінності } \\
\text { університету }\end{array}$} & Польща & 4,00 & \multirow{2}{*}{$-5,83$} & \multirow{2}{*}{$<0,001$} \\
\hline & & Україна & 6,00 & & \\
\hline \multirow{2}{*}{4} & \multirow{2}{*}{ академічна доброчесність } & Польща & 3,00 & \multirow{2}{*}{$-5,68$} & \multirow{2}{*}{$<0,001$} \\
\hline & & Україна & 6,00 & & \\
\hline \multirow{2}{*}{5} & \multirow{2}{*}{ толерантність } & Польща & 8,00 & \multirow{2}{*}{$-5,817$} & \multirow{2}{*}{$<0,001$} \\
\hline & & Україна & 5,00 & & \\
\hline \multirow{2}{*}{6} & \multirow{2}{*}{ лідерство-служіння } & Польща & 2,00 & \multirow{2}{*}{$-9,369$} & \multirow{2}{*}{$<0,001$} \\
\hline & & Україна & 7,00 & & \\
\hline \multirow{2}{*}{7} & \multirow{2}{*}{$\begin{array}{l}\text { відповідальність } \\
\text { та професіоналізм }\end{array}$} & Польща & 4,00 & \multirow{2}{*}{$-1,361$} & \multirow{2}{*}{0,173} \\
\hline & & Україна & 5,00 & & \\
\hline \multirow{2}{*}{8} & \multirow{2}{*}{ громадянська ідентичність } & Польща & 4,00 & \multirow{2}{*}{$-5,824$} & \multirow{2}{*}{$<0,001$} \\
\hline & & Україна & 6,50 & & \\
\hline \multirow{2}{*}{9} & \multirow{2}{*}{$\begin{array}{c}\text { свобода професійної } \\
\text { діяльності }\end{array}$} & Польща & 4,00 & \multirow{2}{*}{$-4,693$} & \multirow{2}{*}{$<0,001$} \\
\hline & & Україна & 5,00 & & \\
\hline \multirow{2}{*}{10} & \multirow{2}{*}{$\begin{array}{c}\text { різноманіття розвитку } \\
\text { особистості }\end{array}$} & Польща & 8,00 & \multirow{2}{*}{$-3,831$} & \multirow{2}{*}{$<0,001$} \\
\hline & & Україна & 6,00 & & \\
\hline
\end{tabular}

Ми ранжували відповіді українських і польських студентів щодо важливості універси- тетських цінностей. Результати представлені в Таблииях 3, 4.

Таблиця 3

Результати ранжування університетських цінностей українськими студентами

\begin{tabular}{|l|c|c|}
\hline \multicolumn{1}{|c|}{ Цінність } & Сума місць & Ранг \\
\hline загальнолюдські моральні цінності & 993 & 1 \\
\hline вільний розвиток особистості & 1042 & 2 \\
\hline відповідальність та професіоналізм & 1063 & 4 \\
\hline толерантність & 1100 & 5 \\
\hline свобода професійної діяльності & 1150 & 6 \\
\hline академічна доброчесність & 1185 & 8 \\
\hline різноманіття розвитку особистості & 1186 & 9 \\
\hline корпоративні цінності університету & 1200 & 10 \\
\hline громадянська ідентичність & 1235 & \\
\hline лідерство-служіння & 1260 & \\
\hline
\end{tabular}

Таблиця 4

Результати ранжування університетських цінностей польськими студентами

\begin{tabular}{|l|c|c|}
\hline \multicolumn{1}{|c|}{ Цінність } & Сума місць & Ранг \\
\hline лідерство-служіння & 463 & 1 \\
\hline академічна доброчесність & 594 & 2 \\
\hline свобода професійної діяльності & 600 & 3 \\
\hline корпоративні цінності університету & 605 & 5 \\
\hline громадянська ідентичність & 624 & 6 \\
\hline відповідальність та професіоналізм & 672 & 7 \\
\hline різноманіття розвитку особистості & 1093 & 8 \\
\hline толерантність & 1113 & 9 \\
\hline вільний розвиток особистості & 1215 & 10 \\
\hline загальнолюдські моральні цінності & 1326 & \\
\hline
\end{tabular}

Українські здобувачі вищої освіти на перші 3 місця поставили загальнолюдські моральні цінності; вільний розвиток особистості; від- повідальність та професіоналізм, тобто українські студенти виявили більшу прихильність до індивідуальних цінностей. 
Для польських студентів найважливішими виявились лідерство-служіння; академічна доброчесність; свобода професійної діяльності. Дивно, але на останньому місці опинились загальнолюдські моральні цінності. Вважаємо, що релігійна спрямованість Єзуїтського університету Ігнатіанум, а також загальнопольські традиційні католицькі цінності обумовили лідерську позицію лідерства-служіння і останню позицію загальнолюдських моральних цінностей, оскільки їхнє місце обіймають цінності католицизму. Як відзначають польські науковці, релігія формує ціннісні орієнтації студентів, що $\epsilon$ потужним джерелом впливу на корпоративну культуру (Mazur, Sulkowski, 2020). Дослідження B. Zarzycka et al. (2016) доводить, що релігійність позитивно корелює з вертикальним колективізмом, що розглядає особистість з іiі індивідуальними особливостями як невід'ємну частину групи. Фізична особа з високим вертикальним колективізмом не тільки відчуває себе частиною колективного органу, а й хоче служити групі і присвятити себе волонтерству, виконанню різних, навіть неприємних завдань заради служіння (B. Zarzycka et al., 2016). Можливо, це пояснює високий ранг лідерства-служіння в порівнянні з вибором українськими студентами, де на перших місцях індивідуальні цінності, а лідерствослужіння опинилось на останньому місці.

Хоча в науковій літературі висвітлюється проблема недотримання студентами принципів академічної доброчесності як в Польщі (Błachnio, 2019), так і в Україні (Luniachek et al., 2020), результати нашого дослідження свідчать, що академічна доброчесність $є$ більш значимою цінністю для польських студентів у порівнянні 3 українськими (2 місце проти 6 відповідно). Таким чином, ми підтверджуємо висновок інших дослідників (Kozolup et al., 2020) про те, що польські студенти у порівнянні з українськими більш нетерпимі до проявів плагіату, а польські університети дотримуються політики нульової толерантності до будь-яких академічних порушень, застосовують санкції та наслідки для порушників академічної нечесності. Хоча існують дослідження, що презентують досить високий рівень академічної недоброчесності студентів Польщі, як і в інших постсоціалістичних країнах, у порівнянні з країнами Європи (Mahmud, 2019).

Більш важливою для польських студентів $€$ громадянська ідентичність (5 позиція проти 9 в українців), а також корпоративні цінності університету (4 позиція проти 8). На наше переконання, це свідчить про більшу соціальну згур- тованість громадян Польщі, а також про більшу прихильність студентів до унікального кодексу поведінки, етичних принципів, цілей та місії рідного закладу вищої освіти. Хоча соціальна згуртованість - явище, яке важко пояснити i, тим більше, виміряти, дослідження Walesiak, Dehnel (2020) свідчить, що Малопольське воєводство Польщі, центром якого $є$ Краків, показало досить високі показники соціальної згуртованості. Відповідних українських досліджень ми не знайшли; наукова розвідка Deineko (2021) стосувалась тільки двох областей України (Харківської і Чернівецької), без Києва.

Українські студенти демонструють часткове розуміння важливості дотримання університетських цінностей, віддаючи перевагу цінностям особистісного розвитку. Ці відмінності у сприйнятті університетських цінностей, на наш погляд, свідчать про різний рівень суспільного сприйняття цінностей академічної спільноти в польському та українському суспільствах (адже студенти - це частина соціуму). Вважаємо також, що цінності сучасного університету мають стати предметом спеціального наукового дискурсу, порядок денний якого включатиме обговорення, серед іншого, питання корпоративної етики, академічної доброчесності, етичного кодексу учасників освітнього процесу тощо.

Висновки i перспективи подальших досліджень. Таким чином, наше дослідження виявило, що польські студенти виявляють більшу прихильність до європейських цінностей, які задекларовані і послідовно впроваджуються в Європейському просторі вищої освіти. Українські студенти більшою мірою орієнтовані на індивідуальні цінності. Ці відмінності, на наш погляд, відбивають і підкреслюють різницю політичних і аксіологічних статусів обох країн: Республіка Польща не тільки політично належить до Європейського Союзу, а й у реальній освітній практиці сповідує європейські морально-етичні цінності. Україна тільки прагне приєднатися до Європейського Союзу, орієнтація на європейські цінності є стратегічною метою нашої країни, проте вони поки що залишаються більшою мірою декларацією про наміри, ніж реальною освітньою практикою. Певною мірою на результати опитування вплинули також релігійні організаційно-світоглядні засади Єзуїтського університету Ігнатіанум і традиційні католицькі цінності польських студентів.

Подальші дослідження будуть спрямовані на міжнародні порівняльні дослідження ціннісних орієнтацій усіх учасників освітнього процесу. 


\section{References}

Akademia Ignatianum w Krakowie. Official web-site. https://ignatianum.edu.pl/misja-i-historia

Amir, A. M., Auzair, S. Md., Maelah, R. and Ahmad, A. (2016). Pricing for Higher Education Institutions: A Value-Based Approach. International Journal of Educational Management , 30 (6), 929-940. https://doi.org/10.1108/IJEM-08-2015-0110

Błachnio, A. (2019). Don’t cheat, be happy. Self-control, self-beliefs, and satisfaction with life in academic honesty: A cross-sectional study in Poland. Scandinavian Journal of Psychology, 60, 261-266. https://doi.org/10.1111/sjop.12534

Borys Grinchenko Kyiv University. Official web-site. https://kubg.edu.ua/prouniversitet/vizytivka/ korporatyvna-kultura-universytetu/1648-tsinnosti-universytetu.html

Boychenko, N. M. (2016). The ethical values of modern university education: philosophical reflection. Doctor's thesis: 09.00.10 - philosophy of education and 09.00.07 - ethics. Institute of higher education of the National academy of pedagogical sciences of Ukraine. https://ihed.org.ua/wpcontent/uploads/2019/01/Boychenko_26.02.2016_disertac.pdf

Cook, S., Watson, D., \& Webb, R. (2019). 'It's just not worth a damn!' Investigating perceptions of the value in attending university. Studies in Higher Education, 44 (7), 1256-1267. https://doi.org/10.1080/ 03075079.2018.1434616

Cavallone, M., Ciasullo, M. V., Manna, R. \& Palumbo, R. (2020). A tale of two stakeholders: achieving excellence by merging quality expectations in Higher Education institutions, Studies in Higher Education. 10.1080/03075079.2020.1739016

Deineko, O. O. (2021). Social cohesion in decentralized Ukraine: From old practices to new order. Studia Socjologiczne, 1 (240), 117-138. 10.24425/sts.2021.136281

Dlačić, J., Arslanagić, M., Kadić-Maglajlić, S., Marković, S., \& Raspor, S. (2013). Exploring Perceived Service Quality, Perceived Value, and Repurchase Intention in Higher Education Using Structural Equation Modelling. Total Quality Management and Business Excellence, 25 (1-2), 141-157. https://doi.org/10.1080/14783363.2013.824713

Dollinger, M., Lodge, J., and Coates, H. (2018). Co-Creation in Higher Education: Towards a Conceptual Model. Journal of Marketing for Higher Education, 28 (2), 210-231.

Dollinger, M., and Mercer-Mapstone, L. (2019). What's in a Name? Unpacking students' Roles in Higher Education through Neoliberal and Social Justice Lenses. Teaching \& Learning Inquiry, 7 (2), 73-89. https://doi.org/10.20343/teachlearninqu.7.2.5.

Dollinger, M., and J. Lodge (2020). Student-Staff Co-Creation in Higher Education: An Evidence-Informed Model to Support Future Design and Implementation. Journal of Higher Education Policy and Management, 42 (5), 532-546. 10.1080/1360080X.2019.1663681.

Dziewanowska, K. (2017). Value Types in Higher Education - Students' Perspective. Journal of Higher Education Policy and Management, 39 (3), 235-246. https://doi.org/10.1080/1360080X.2017.1299981

Fajčiková, A. and Urbancová, H. (2019). Factors Influencing Students' Motivation to Seek Higher Education A Case Study at a State University in the Czech Republic. Sustainability, 11 (17), 1-14. https://doi. org/10.3390/su11174699

Foltýnek, T., Glendinning, I. (2015). Impact of policies for plagiarism in higher education across europe: results of the project. Acta Universitatis Agriculturae et Silviculturae Mendelianae Brunensis, 63 (1), 207-216. 10.11118/actaun201563010207

Hilton, T., Hughes, T., \& Chalcraft, D. (2012). Service co-creation and value realisation. Journal of Marketing Management, 28 (13-14), 1504-1519. https://doi.org/10.1080/0267257X.2012.736874

Holten, A.-L. and Brenner, S.O. (2015). Leadership style and the process of organizational change. Leadership \& Organization Development Journal, 36 (1), 2-16. https://doi.org/10.1108/LODJ-11-2012-0155

Hughes, T., and Brooks, I. (2019). Co-Creation of Value - A Customer-Integration Approach. In B. Nguyen, T. Melewar, and J. Hemsley-Brown (Ed.), Strategic Brand Management in Higher Education (pp. 159-176). Routledge.

Jaakson, K. (2008). Students' Perceptions about University Values: Some Influencing Factors. Journal of Human Values, 14 (2), 169-180. https://doi.org/10.1177/097168580801400207

Kay, J., Owen, D., \& Dunne, E. (2012). Students as change agents: Student engagement with quality enhancement of learning and teaching. In A. R. I. Solomonides \& P. Petocz (Eds.), Engaging with learning in higher education (pp. 359-380). Oxfordshire: Libri Publishers. 
Kozolup, M., Kokor, M., Savchynskyi, R. (2020). Polish and Ukrainian University Students' Perspectives on Academic Writing: A Comparative Overview. Central European Journal of Communication, 3 (27). https://doi.org/10.51480/1899-5101.13.3(27).3

Luniachek, V., Brovdii, A., Kulakovskyi, O., Varenko, T. (2020). Academic Integrity in Higher Education of Ukraine: Current State and Call for Action. Education Research International, 2020, 8856251. https://doi.org/10.1155/2020/8856251

Mahmud, S., Bretag, T. \& Foltýnek, T. (2019). Students' Perceptions of Plagiarism Policy in Higher Education: a Comparison of the United Kingdom, Czechia, Poland and Romania. Journal of Academic Ethics, 17, 271-289. https://doi.org/10.1007/s10805-018-9319-0

Mamica, Ł., Mazur, B. (2020). Expectations Versus Reality: What Matters to Students of Economics vs. What They Receive from Universities? Education Sciences, 10 (1). https://doi.org/10.3390/ educsci10010002

Mazur, B., Sulkowski, L. (2020). Management students values depending on religion-comparative research from Poland. Social Sciences, 9 (2). https://doi.org/10.3390/socsci9020018

Sampaio, C. H., Perin, M. G., Simões, C. and Kleinowski, H. (2012). Students' Trust, Value and Loyalty: Evidence From Higher Education in Brazil. Journal of Marketing for Higher Education, 22 (1), 83-100. https://doi.org/10.1080/08841241.2012.705796

The Bucharest Declaration concerning Ethical Values and Principles for Higher Education in the Europe Region (2004). Higher Education in Europe, 29 (4), 503-507. https://doi.org/10.1080/03797720500083922

Vilà, R., Aneas, A., Rubio, M. J., Freixa, M. (2019). The Value of Student Engagement for Higher Education Quality Assurance. Moving Away from the Regulatory Approach. REICE. Revista Iberoamericana sobre Calidad, Eficacia y Cambio en Educación, 17 (2), 107-122. https://doi.org/10.15366/ reice2019.17.2.006

Walesiak, M., Dehnel, G. (2020). The Measurement of Social Cohesion at Province Level in Poland Using Metric and Interval-Valued Data.Sustainability, 12 (18), 7664.https://doi.org/10.3390/su12187664

Zarzycka, B., Tychmanowicz, A., Goździewicz-Rostankowska, A. (2016). The Interplay between Religiosity and Horizontal and Vertical Individualism-Collectivism among Polish Catholic Students. Polish Psychological Bulletin, 47 (3), 383-393. 10.1515/ppb-2016-0045

\section{WARTOŚCI UNIWERSYTECKIE \\ W INSTYTUCJACH SZKOLNICTWA WYŻSZEGO UKRAINY I RZECZYPOSPOLITEJ POLSKIEJ: OPINIE STUDENTÓW}

\section{Procenko Olena}

ORCID iD 0000-0001-5046-854X

Kandydat nauk pedagogicznych, profesor nadzwyczajny,

Kierownik naukowo-badawczego Laboratorium Oświatologii,

Kijowski uniwersytet im. B. Grinczenki,

ul.Tymoszenki, 13-b, 04212 Kijów, Ukraina,

o.protsenko@kubg.edu.u

Bulwinska Oksana

ORCID iD 0000-0002-6764-4340

Kandydat nauk pedagogicznych, starszy pracownik naukowy

naukowo-badawczego Laboratorium Oświatologii, Kijowski uniwersytet im. B. Grinczenki,

ul. Tymoszenki, 13-b, 04212 Kijów, Ukraina,

o.bulvinska@kubg.edu.ua

Melnyczenko Olga

ORCID iD 0000-0002-5297-9551

Kandydat nauk historycznych, profesor nadzwyczajny,

profesor nadzwyczajny Wydziału teorii i historii pedagogiki Instytutu Pedagogicznego,

Kijowski uniwersytet im. B. Grinczenki bul. I. Shamo 18/2, melnyenko@kubg.edu.ua 


\author{
Charchuła Jarosław \\ ORCID iD 0000-0002-8470-7374 \\ Doktor nauk humanistycznych z zakresu socjologii $(\mathrm{PhD})$, \\ Zastępca Dyrektora Instytutu Nauk o Wychowaniu ds. Dydaktycznych, \\ Akademia Ignatianum w Krakowie,ul. Kopernika 26, \\ 31-501 Kraków, Rzeczpospolita Polska, \\ jaroslaw.charchula@ignatianum.edu.pl
}

W artykule na podstawie własnych badań eksperymentalnych, przeprowadzono analizę porównawczą stosunku studentów ukraińskich i polskich uczelni do wartości akademickich uniwersytetu. Zwraca się uwagę, że moralne i etyczne wartości kultury akademickiej, sformułowane w „Deklaracji Wartości Etycznych i Zasad Szkolnictwa Wyższego w Europie", sq realizowane we wszystkich aspektach działalności uczelni, w szczególności polskich. Ukraina, której strategicznym celem jest przystapienie do Unii Europejskiej, reformuje swój system edukacji zgodnie z wartościami Europejskiego Obszaru Szkolnictwa Wyższego. Podkreśla się, że system wspólnych wartości, postaw, norm, zwyczajów, tradycji, form zachowań i rytuałów, nie tylko deklarowanych, ale także popieranych przez wszystkich członków społeczności uniwersyteckiej, jest ważnym elementem unikalnej kultury korporacyjnej uczelni, warunkująca jej sukces organizacyjny, przyczynia się do podnoszenia jakości kształcenia. Badanie, przeprowadzone na podstawie ankiety wśród studentów Instytutu Pedagogicznego Kijowskiego Uniwersytetu im. Borysa Grinchenki oraz Wydziału Pedagogicznego Uniwersytetu Ignatianum, wykazało, że polscy studenci wykazuja większe przywiqzanie do deklarowanych $i$ konsekwentnie realizowanych wartości europejskich w Europejskim Obszarze Szkolnictwa Wyższego; Ukraińscy studenci sq bardziej skoncentrowani na indywidualnych wartościach. Wyniki te potwierdzaja różnice w statusie politycznym $i$ aksjologicznym obu krajów.

Słowa kluczowe: szkolnictwo wyższe; Europejski Obszar Szkolnictwa Wyższego; kultura uczelni korporacyjnej; studenci; wartości uniwersyteckie.

\title{
UNIVERSITY VALUES AT HIGHER EDUCATION INSTITUTIONS OF UKRAINE AND THE REPUBLIC OF POLAND: STUDENTS' VIEW
}

\author{
Protsenko Olena \\ ORCID iD 0000-0001-5046-854X \\ Candidate of Pedagogical Sciences, Associate Professor, \\ Head of the Educology Research Laboratory, Borys Grinchenko Kyiv University, \\ 13-b Tymoshenko Str., 04212 Kyiv, Ukraine, \\ o.protsenko@kubg.edu.ua \\ Bulvinska Oksana \\ ORCID iD 0000-0002-6764-4340 \\ Candidate of Pedagogical Sciences, Senior Researcher, \\ Senior Researcher of Scientific-Research Laboratory of Educology, \\ Borys Grinchenko Kyiv University, 13-b Tymoshenko Str., 04212 Kyiv, Ukraine, \\ o.bulvinska@kubg.edu.ua \\ Melnychenko Olga \\ ORCID iD 0000-0002-5297-9551
}

Candidate of Historical Sciences, Associate Professor, Department of Theory and History of Pedagogy,

Borys Grinchenko Kyiv University, Pedagogical Institute,

I. Shamo Boulevard 18/2, 02154 Kiev, Ukraine, melnychenko@kubg.edu.ua

Charkhula Yaroslav

ORCID iD 0000-0002-8470-7374

Doctor of Humanities in Sociology (PhD), Deputy Director of the Institute 
of Pedagogical Sciences in Didactics, Ignatius Academy in Krakow,

26 Kopernika Str., 31-501 Krakow, Poland,

jaroslaw.charchula@ignatianum.edu.pl

On the basis of the personal experimental research, a comparative analysis of the students' attitude at Ukrainian and Polish higher educational institutions to university academic values, has been carried out in the article. It has been noted that the moral and ethical values of academic culture, formulated in the "Declaration concerning Ethical Values and Principles for Higher Education in the Europe Region", are implemented in all aspects of the universities' activities, in particular at Polish ones. Ukraine, whose strategic goal is to join the European Union, is reforming its education system in accordance with the values of the European Higher Education Area. It has been emphasized that the system of common values, relationships, norms, habits, traditions, forms of behavior and rituals, not only declared, but also supported by all members of the university community, is an important element of the unique corporate culture of a higher education institution; it determines its organizational success, contributes to education quality improvement. The study, conducted on the basis of the students' survey at Pedagogical Institute of Kyiv Borys Grinchenko University and the Pedagogical Faculty of the Jesuit University Ignatianum, revealed that Polish students show a greater commitment to European values, which are declared and are consistently implemented in the European Higher Education Area; Ukrainian students are more focused on individual values. These results confirm the differences in the political and axiological status of both countries.

Keywords: higher education; European Higher Education Area; corporate university culture; students; university values.

Стаття надійшла до редакиії 15.08.2021

Прийнято до друку 28.10.2021 